\title{
STATUS KESEHATAN POHON PADA JALUR HIJAU DAN HALAMAN PARKIR UNIVERSITAS LAMPUNG
}

\section{(TREE HEALTH STATUS ON THE GREEN LINE AND THE PARKING AREA UNIVERSITY OF LAMPUNG)}

\author{
Ekindo Vanesah Sitinjak, Duryat, dan Trio Santoso \\ Jurusan Kehutanan Fakultas Pertanian Universitas Lampung, \\ J1. Soemantri Brojonegoro No. 1 Bandar Lampung \\ E-mail : ekindositinjak@gmail.com \\ No. Telepon : 082280678063
}

\begin{abstract}
ABSTRAK
Kampus Universitas Lampung merupakan salah satu bentuk ruang terbuka hijau perkotaan yang memilki manfaat ekologi, sosial, budaya, dan estetika. Seringnya kejadian dahan patah dan pohon tumbang mengindikasikan bahwa banyak pohon yang mengalami kondisi yang kurang baik. Identifikasi status kesehatan pohon merupakan upaya penting dalam pengelolaan pohon, sesuai kaidah silvikultur untuk menjaga kesehatan pohon hutan. Penelitian ini bertujuan (1) untuk mengetahui status kesehatan pohon-pohon di jalur hijau dan halaman parkir Universitas Lampung, (2) mengetahui bentuk serangan hama dan penyakit yang menyebabkan kerusakan pada pohon, serta gangguan manusia yang terdapat pada pohon-pohon di jalur hijau dan halaman parkir Unila. Identifikasi status kesehatan pohon dilakukan dengan metode Pemantau Kesehatan Hutan atau Forest Health Monitoring (FHM). Hasil penelitian menujukkan bahwa sebagian besar kondisi pohon di jalur hijau dan halaman parkir di lingkungan Universitas Lampung berada pada kondisi sehat $(92,29 \%)$, dan hanya sebagian kecil $(7,81 \%)$ yang berada pada kondisi rusak ringan, rusak sedang, dan rusak berat. Secara umum terdapat 9 tipe kerusakan pohon yang paling sering ditemukan pada pohon-pohon penyusun vegetasi jalur hijau dan halaman parkir Unila. Kerusakan-kerusakan yang dialami adalah perubahan warna daun (10,48\%), luka terbuka $(10,38 \%)$, tubuh buah $(4,11 \%)$, kanker $(3,80 \%)$, epifit $(2,26 \%)$, kerusakan tunas daun $(1,23 \%)$, patah cabang/batang $(1,54 \%)$, branchis $(0,92 \%)$, dan resinosis $(0,51 \%)$.
\end{abstract}

Kata Kunci : Forest Health Monitoring (FHM), hutan kota Unila, kesehatan pohon, penyakit tanaman

\begin{abstract}
Campus of University Lampung was one of the urban green open spaces which has ecological, social, cultural, and aesthetic. The frequency of broken branches and fallen trees indicated that many of trees were in unfavorable conditions. Identification of the tree health status was an important effort in order to manage trees properly, according to silviculture theorems. The study aimed (1) to figure out the trees health status in the green line along the street and parking area in University of Lampung, (2) figure out pests and diseases and also and human disturbance that cause the tree damage. The Forest Health Monitoring (FHM) method was employed to identifie the tree health status. The result of research showed that, majority (92.29\%) of trees in the green line and the parking area of Lampung University were in health condition, and only a small percentage $(7,81 \%)$ were identified in light damaged, medium demaged, and hard damaged.
\end{abstract}


Generally, there were nine types of tree damage that most found. Those damage were discoloration of leaves (10.48\%), open wounds (10.38\%), fruiting bodies $(4.11 \%)$, cancer (3.80\%), epifit (2.26\%), leaf buds damage (1.23\%), fractures branches/trunks (1.54\%), branchis $(0.92 \%)$, and resinosis $(0.51 \%)$.

Keywords: Forest Health Monitoring (FHM), urban forest of Unila, tree health, plant diseases

\section{PENDAHULUAN}

Kampus Universitas Lampung merupakan salah satu bentuk ruang terbuka hijau perkotaan yang memilki manfaat ekologi, sosial, budaya, dan estetika. Universitas Lampung (Unila) sering juga disebut kampus hijau karena luas proporsi Ruang Terbuka Hijau (RTH) Unila yang mencapai lebih dari $60 \%$ dan kondisi vegetasi di lingkungan Unila didominasi pepohonan. Pohon di dalam kawasan Unila sangat heterogen, dan sampai saat ini terdapat lebih kurang 100 jenis pohon yang tersebar di seluruh wilayah Unila (Syam dkk., 2007).

Pepohonan yang berada di kampus Unila saat ini diduga banyak yang mengalami kondisi yang kurang baik. Banyak pohon telah berumur tua dan terserang hama/penyakit sehingga berpotensi mengalami kematian atau tumbang. Kondisi ini sangat membahayakan keselamatan warga civinitas akademika Unila serta masyarakat yang berkunjung ke lingkungan Unila. Oleh karena itu perlu adanya informasi dan pemantauan tentang kondisi kesehatan pohon-pohon sehingga dapat digunakan sebagai dasar pemeliharaan terhadap pohon yang berada di RTH Unila khususnya areal jalur hijau dan halaman parkir.

Kondisi kesehatan pohon di areal jalur hijau dan halaman parkir Unila perlu diketahui untuk dijadikan informasi, bagi tindakan perawatan yang dapat dilakukan pada pohon yang tidak sehat. Identifikasi status kesehatan pohon merupakan upaya penting dalam pengelolaan pohon, sesuai kaidah silvikultur untuk menjaga kesehatan pohon hutan dengan tahap-tahap mengendalikan (controlling), memfasilitasi (facilitating), melindungi (protecting) dan menyelamatkan (salvaging) (Duryat dkk., 2014). Tujuan dari penelitian adalah untuk mengetahui status kesehatan pohon serta bentuk serangan hama dan penyakit yang menyebabkan kerusakan pada pohon serta gangguan manusia yang terdapat pada pohon-pohon di lingkungan Unila khususnya jalur hijau dan halaman parkir.

\section{METODE PENELITIAN}

\section{Waktu dan Tempat Penelitian}

Penelitian dilaksanakan bulan April-Mei 2015 di seluruh jalur hijau dan halaman parkir di Universitas Lampung, Bandar Lampung.

\section{Alat dan Bahan}

Alat-alat yang digunakan dalam penelitian ini adalah Peta Universitas Lampung, pita ukur diameter, binokuler, haga meter, Global Positioning System (GPS) garmin 64s, kamera digital (Sony DSC-H300), dan software ms. Excel. Bahan yang digunakan adalah pohon-pohon yang tumbuh pada seluruh jalur hijau dan halaman parkir Unila. 


\section{Metode Penelitian}

Penelitian dilakukan dengan metode sensus yaitu dengan analisis vegetasi untuk menganalisis seluruh pohon yang ada di jalur hijau dan halaman parkir Unila. Identifikasi status kesehatan pohon dilakukan dengan metode Pemantau Kesehatan Hutan atau Forest Health Monitoring (FHM), yaitu metode penilaian kesehatanan pohon dengan mengelompokkan jenis dan tingkat kerusakan per individu tanaman. Penggolongan tingkat kerusakan pohon didasarkan pada tiga kriteria yaitu lokasi kerusakan, bentuk kerusakan, dan tingkat keparahan. Status kesehatan pohon dipetakan dengan mengambil titik koordinat pohon menggunakan GPS. Setiap pohon kemudian diberikan kode sesuai dengan posisi dan urutan sebenarnya di lapangan.

\section{HASIL DAN PEMBAHASAN}

\section{Status Kesehatan Pohon di Jalur Hijau dan Halaman Parkir Universitas Lampung (Unila)}

Hasil penelitian menunjukkan jumlah pohon penyusun vegetasi jalur hijau dan halaman parkir Unila berjumlah 973 pohon yang terdiri atas 61 spesies. Hasil penelitian menunjukkan bahwa sebagian besar $(92,19 \%)$ kondisi pohon di jalur hijau dan halaman parkir di lingkungan Universitas Lampung berada pada kondisi sehat dan hanya sebagian kecil $(7,81 \%)$ yang berada pada kondisi rusak sedang dan rusak berat. Secara lengkap Status Kesehatan Pohon di Jalur Hijau dan Halaman Parkir Universitas Lampung (Unila) disajikan pada Tabel 1. Dibandingkan dengan pohon-pohon yang berada pada jalur hijau di Kota Bandar Lampung, pohon-pohon yang berada pada jalur hijau dan halaman parkir Unila lebih sehat. Sesuai dengan yang dilaporkan Duryat dkk.(2014), bahwa sebanyak 6\% pohon-pohon yang berada di jalur hijau kota Bandar Lampung berada pada kondisi rusak sedang dan rusak berat. Hal ini diduga karena pohon-pohon yang berada pada jalur hijau dan halaman parkir Unila terpapar lebih sedikit polutan dibandingkan dengan pohon-pohon yang berada di jalur hijau kota Bandar Lampung. Kondisi ini dikarenakan dengan jumlah kendaraan yang melintas di jalur hijau kota Bandar Lampung yang merupakan jalan umum lebih banyak dibandingkan dengan kawasan Unila.

Tabel 1. Status Kesehatan Pohon di Jalur Hijau dan Halaman Parkir Universitas Lampung.

\begin{tabular}{lcc}
\hline \multicolumn{1}{c}{ Kelas Kondisi Kesehatan Pohon } & Jumlah & Persentase (\%) \\
\hline Sehat & 897 & 92,19 \\
Rusak Ringan & 42 & 4,32 \\
Rusak Sedang & 26 & 2,67 \\
Rusak Berat & 8 & 0,82 \\
\hline Total & 973 & 100,00 \\
\hline
\end{tabular}

Kondisi kesehatan pohon di jalur hijau Kota Bandar Lampung pada umumnya lebih buruk dibandingkan dengan pohon-pohon yang berada di jalur hijau dan halaman parkir Unila juga karena tingginya eksploitasi terhadap pohon di jalur hijau untuk digunakan sebagai media sosialisasi maupun promosi bagi produk-produk barang dan jasa serta sarana kampanye parpol dan politisi. Cara pelaku bisnis, parpol dan politisi untuk memperkenalkan produk dan mensosisalisasikan diri kurang memperhatikan kaidah kesehatan pohon. Pelaku bisnis, dan politisi biasanya menggunakan paku, tali tambang, dan kawat yang dipasang pada pohon, sehingga berpotensi menimbulkan luka terbuka. Luka yang terjadi itu akan menjadi media 
masuknya patogen ke dalam tubuh pohon sehingga menurunkan kondisi kesehatan pohon. Sebagaimana yang telah dilakukan penelitian Siregar (2014) bahwa pelaku bisnis, dan politisi biasanya menancapkan paku atau tambang plastik, dan kawat untuk menenpelkan spanduk, banner, poster, maupun pamflet pada batang pohon peneduh jalan.

\section{Status Kesehatan Pohon Berdasarkan Lokasi Tempat Tumbuh}

Hasil penelitian menunjukkan bahwa kondisi kesehatan pohon di halaman parkir secara umum lebih baik dibandingkan pohon-pohon yang berada pada jalur hijau. Persentase pohon yang berada pada kondisi rusak sedang dan rusak berat di jalur hijau berjumlah 8,32\% , sementara pada halaman parkir pohon yang berada pada kondisi rusak sedang dan rusak berat hanya berjumlah $6,2 \%$. Hal ini diduga karena pohon yang berada di jalur hijau terpapar lebih banyak polutan dan mengalami eksploitasi yang lebih besar dibandingkan dengan pohon yang berada di halaman parkir. Jumlah kendaraan yang melintas di jalur hijau lebih banyak dibandingkan yang melintas di halaman parkir. Selain itu publikasi dan iklan yang dipasang juga lebih banyak dijumpai di jalur hijau daripada yang ada di halaman parkir. Secara lengkap status kesehatan pohon berdasarkan lokasi tempat tumbuh disajikan pada Tabel 2.

Tabel 2. Status Kesehatan Pohon Berdasarkan Lokasi Tempat Tumbuh.

\begin{tabular}{lcccc}
\hline \multirow{2}{*}{$\begin{array}{c}\text { Kelas Kondisi Kesehatan } \\
\text { Pohon }\end{array}$} & \multicolumn{2}{c}{ Jumlah } & \multicolumn{2}{c}{ Persentase } \\
\cline { 2 - 5 } & Jalur Hijau & $\begin{array}{c}\text { Halaman } \\
\text { Parkir }\end{array}$ & $\begin{array}{c}\text { Jalur Hijau } \\
(\%)\end{array}$ & $\begin{array}{c}\text { Halaman } \\
\text { Parkir }(\%)\end{array}$ \\
\hline Sehat & 670 & 227 & 91,66 & 93,80 \\
Rusak Ringan & 30 & 11 & 4,10 & 4,55 \\
Rusak Sedang & 23 & 3 & 3,15 & 1,24 \\
Rusak Berat & 8 & 1 & 1,09 & 0,41 \\
\hline \multicolumn{1}{c}{ Total } & 731 & 242 & 100,00 & 100,00 \\
\hline
\end{tabular}

Aktivitas manusia untuk menghasilkan energi, industri, dan pembuangan limbah menyebabkan terlepasnya sejumlah polutan ke atmosfer yang mengganggu metabolisme tumbuhan dan memicu timbulnya penyakit abiotik (Sumardi dkk., 2004). Polutan yang terdapat di jalur hijau Unila disebabkan dari asap kendaraan bermotor. Bahan pencemar yang terutama terdapat di dalam gas buang kendaraan bermotor adalah karbon monoksida (CO), berbagai senyawa hindrokarbon, berbagai oksida nitrogen (NOx), dan sulfur (SOx), dan partikulat debu termasuk timbal (PB). Gas-gas oksidan seperti O3, SO2, NO2, diketahui sebagai senyawa meracun yang dapat menimbulkan kerusakan pada proses fotosintesis tumbuhan (Sumardi dan Widyastuti, 2004).

\section{Status Kesehatan Pohon Berdasarkan Wilayah Tempat Tumbuh}

Hasil penelitian menunjukkan bahwa berdasarkan wilayah tempat tumbuhnya, secara umum pohon-pohon yang berada di GSG, Perpustakaan, UPT Teknologi Informasi dan Komunikasi, Kolam Renang, Rektorat Fakultas Hukum, dan FSIP berada pada kondisi yang paling baik dibandingkan wilayah lain, dengan $100 \%$ pohon berada pada kondisi sehat. Sementara secara umum kondisi pohon terburuk adalah pohon-pohon yang berada di Fakultas Matematika dan Ilmu Pengetahuan Alam dengan 10,66\% pohon yang mengalami kondisi rusak 
sedang dan rusak berat. Hal ini dikarenakan jumlah pohon di wilayah lokasi tempat tumbuh GSG, Perpustakaan, UPT Teknologi Informasi dan Komunikasi, Kolam Renang, Rektorat, Fakultas Hukum, dan FSIP yang relatif sedikit dibandingkan jumlah pohon yang berada pada fakultas MIPA. Secara lengkap status kesehatan pohon berdasarkan wilayah tempat tumbuh disajikan pada Tabel 3.

Jumlah pohon yang relatif sedikit mengurangi kompetisi dan interfensi antar pohon penyusun tegakan sehingga pohon mendapatkan ruang tumbuh yang cukup baik dalam memperoleh ketercukupan unsur hara. Kompetisi dan interfensi antar pohon penyusun tegakan dapat berpengaruh melemahkan atau mematikan pohon (Nyland, 1996; Sumardi dkk., 2004). Jumlah pohon yang relatif sedikit akan menyebabkan jarak tanam yang cukup lebar antar tanaman. Sesuai dengan penelitian ini jarak tanam pohon-pohon yang berada di GSG, Perpustakaan, UPT Teknologi Informasi dan Komunikasi, Kolam Renang, Rektorat Fakultas Hukum, dan FSIP memiliki jarak tanam yang cukup lebar.

Tabel 3. Status Kesehatan Pohon Berdasarkan Wilayah Tempat Tumbuh.

\begin{tabular}{|c|c|c|c|c|c|c|c|c|}
\hline \multirow[b]{2}{*}{ Lokasi } & \multicolumn{4}{|c|}{ Jumlah } & \multicolumn{4}{|c|}{ Persentase } \\
\hline & Sehat & $\begin{array}{c}\text { Rusak } \\
\text { Ri- } \\
\text { ngan }\end{array}$ & $\begin{array}{c}\text { Rusak } \\
\text { Se- } \\
\text { dang }\end{array}$ & $\begin{array}{c}\text { Rusak } \\
\text { Berat }\end{array}$ & $\begin{array}{c}\text { Sehat } \\
(\%)\end{array}$ & $\begin{array}{c}\text { Rusak } \\
\text { Ri- } \\
\text { ngan } \\
(\%)\end{array}$ & $\begin{array}{c}\text { Rusak } \\
\text { Se- } \\
\text { dang } \\
(\%)\end{array}$ & $\begin{array}{c}\text { Rusak } \\
\text { Berat } \\
(\%)\end{array}$ \\
\hline GSG & 73 & 0 & 0 & 0 & 100,00 & 0,00 & 0,00 & 0,00 \\
\hline Perpustakaan & 7 & 0 & 0 & 0 & 100,00 & 0,00 & 0,00 & 0,00 \\
\hline Pusat Komunikasi & 10 & 0 & 0 & 0 & 100,00 & 0,00 & 0,00 & 0,00 \\
\hline Pusat Komunikasi & 10 & 0 & 0 & 0 & 100,00 & 0,00 & 0,00 & 0,00 \\
\hline Kolam Renang & 19 & 0 & 0 & 0 & 100,00 & 0,00 & 0,00 & 0,00 \\
\hline Rektorat & 6 & 0 & 0 & 0 & 100,00 & 0,00 & 0,00 & 0,00 \\
\hline FSIP & 13 & 0 & 0 & 0 & 100,00 & 0,00 & 0,00 & 0,00 \\
\hline Fakultas Hukum & 5 & 0 & 0 & 0 & 100,00 & 0,00 & 0,00 & 0,00 \\
\hline Pusat Komunikasi & 10 & 0 & 0 & 0 & 100,00 & 0,00 & 0,00 & 0,00 \\
\hline Kolam Renang & 19 & 0 & 0 & 0 & 100,00 & 0,00 & 0,00 & 0,00 \\
\hline Fakultas & 35 & 1 & 0 & 0 & 97,22 & 2,78 & 0,00 & 0,00 \\
\hline Kedokteran & & & & & & & & \\
\hline Fakultas Teknik & 154 & 2 & 3 & 1 & 96,25 & 1,25 & 1,88 & 0,63 \\
\hline Lapangan Bola & 84 & 1 & 2 & 1 & 95,45 & 1,14 & 2,27 & 1,14 \\
\hline Fakultas & 106 & 7 & 1 & 0 & 92,98 & 6,14 & 0,88 & 0,00 \\
\hline Pertanian & & & & & & & & \\
\hline $\begin{array}{l}\text { Fakultas Ekonomi } \\
\text { dan Bisnis }\end{array}$ & 24 & 1 & 1 & 0 & 92,31 & 3,85 & 3,85 & 0,00 \\
\hline FKIP & 71 & 7 & 0 & 0 & 91,03 & 8,97 & 0,00 & 0,00 \\
\hline UPT Bahasa & 8 & 1 & 0 & 0 & 88,89 & 11,11 & 0,00 & 0,00 \\
\hline Jalur Soemantri & 224 & 13 & 12 & 5 & 88,19 & 5,12 & 4,72 & 1,97 \\
\hline Brojonegoro & & & & & & & & \\
\hline Fakultas MIPA & 58 & 9 & 7 & 1 & 77,33 & 12,00 & 9,33 & 1,33 \\
\hline Total & 897 & 42 & 26 & 8 & & & & \\
\hline
\end{tabular}


Jarak tanam berpengaruh terhadap besarnya intensitas cahaya dan ketersediaan unsur hara yang dibutuhkan bagi tanaman. Semakin lebar jarak tanam, semakin besar intensitas cahaya dan semakin banyak ketersediaan unsur hara bagi individu tanaman, karena jumlah pohonnya lebih sedikit. Sebaliknya semakin rapat jarak tanam semakin banyak jumlah pohonnya dan persaingan semakin ketat (Mawazin dan Suhaendi., 2008). Ruang tumbuh yang lebih besar memungkinkan jangkauan perakaran pohon menjadi lebih luas, dan nutrisi yang dibutuhkan oleh tumbuhan akan dapat dipenuhi (Duryat dkk., 2014).

Tipe Kerusakan yang Paling Banyak Ditemukan di Jalur Hijau dan Halaman Parkir Unila

Hasil penelitian menujukkan bahwa tipe kerusakan pohon yang paling banyak ditemukan di jalur hijau dan halaman parkir Universitas Lampung adalah perubahan warna daun dan luka terbuka dengan masing-masing $10,48 \%$ dan $10,38 \%$ dari seluruh tipe kerusakan pohon. Kerusakan yang terjadi pada daun berupa perubahan warna ini diduga disebabkan oleh klorosis yang disebabkan oleh kekurangan unsur Nitrogen. Hal ini dikarenakan bentuk perubahan warna daun terjadi mula-mula pada ujung daun dan kemudian merambat sampai pangkal daun. Sesuai dengan gejala kekurangan unsur Nitrogen dapat terlihat dimulai dari daunnya, warnanya yang hijau agak kekuning-kuningan selanjutnya berubah menjadi kuning lengkap (Yudiarti, 2012). Secara lengkap tipe kerusakan yang paling banyak ditemukan di jalur hijau dan halaman parkir unila disajikan pada Tabel 4.

Tabel 4. Tipe Kerusakan yang Paling Banyak Ditemukan di Jalur Hijau dan Halaman Parkir Unila.

\begin{tabular}{lcc}
\hline \multicolumn{1}{c}{ Tipe Kerusakan } & $\begin{array}{c}\text { Jumlah } \\
\text { Terserang (Pohon) }\end{array}$ & Persentase (\%) \\
\hline Perubahan Warna Daun & 102 & 10,48 \\
Luka Terbuka & 101 & 10,38 \\
Tubuh buah (Keropos, jamur) & 40 & 4,11 \\
Kanker & 37 & 3,80 \\
Tumbuhan Penggangu & 22 & 2,26 \\
Kerusakan Tunas Daun & 12 & 1,23 \\
Patah Cabang/Batang & 15 & 1,54 \\
Branchis & 9 & 0,92 \\
Resinosis & 5 & 0,51 \\
\hline \multicolumn{2}{c}{ Total } & 343 \\
\hline
\end{tabular}

Klorosis yaitu proses menguningnya jaringan tanaman yang disebabkan degradasi klorofil dan gagalnya pembentukan klorofil. Gejala klorosis disebabkan karena terbatasnya sintesa klorofil akibat defisiensi Nitrogen $(\mathrm{N})$. Pada dasarnya unsur $\mathrm{N}$ merupakan unsur esensial dan unsur hara makro. Nitrogen bersifal mobil dan ditranslokasikan dari jaringan tua ke jaringan yang lebih muda (Sumardi dan Widyastuti, 2012). Meskipun nantinya akan terbentuk jaringan daun baru yang sehat, namun kerusakan ini dapat mempengaruhi fotosintesis (Rahayu, 1999; Triwibowo dkk., 2014).

Luka terbuka adalah suatu luka atau serangkaian luka yang ditunjukkan dengan mengelupasnya kulit atau kayu bagian dalam kayu telah terbuka dan tidak ada tanda lapuk lanjut (Mangold, 1997). Luka terbuka yang ditemukan berupa pengelupasan kulit batang pohon yang 
disebabkan akvitas manusia. Beberapa kerusakan luka terbuka yang dijumpai dari aktivitas manusia menunjukkan perlukaan akibat bekas publikasi. Luka yang terjadi itu akan menjadi media masuknya patogen ke dalam tubuh pohon sehingga menurunkan kondisi kesehatan pohon (Stalin dkk., 2011).

\section{Lokasi Kerusakan yang Paling Banyak Ditemukan}

Hasil penelitian diketahui bahwa lokasi kerusakan pohon paling sering terjadi di bagian daun $(11,41 \%)$. Sementara lokasi kerusakan yang paling jarang ditemukan adalah pada batang tajuk dengan persentase $0,72 \%$. Lokasi kerusakan yang sering ditemukan pada bagian daun dan batang tajuk menurut metode FHM merupakan lokasi kerusakan yang kurang berbahaya karena paling ringan pengaruhnya terhadap kematian pohon. Secara lengkap lokasi kerusakan yang paling banyak ditemukan disajikan pada Tabel 5.

Tabel 5. Lokasi Kerusakan yang Paling Banyak Ditemukan.

\begin{tabular}{lcc}
\hline \multicolumn{1}{c}{ Lokasi Kerusakan } & $\begin{array}{c}\text { Jumlah Terserang } \\
\text { (Pohon) }\end{array}$ & $\begin{array}{c}\text { Persentase } \\
(\%)\end{array}$ \\
\hline Daun & 111 & 11,41 \\
Batang bagian bawah & 105 & 10,79 \\
Akar dan batang bagian bawah & 52 & 5,34 \\
Akar (terbuka dan tunggak) & 12 & 1,23 \\
Batang bagian atas & 37 & 3,80 \\
Cabang & 16 & 1,64 \\
Batang bagian bawah dan atas & 14 & 1,44 \\
Batang tajuk (batang utama di dalam & 7 & 0,72 \\
daerah tajuk hidup) & & 36,37 \\
\hline \multicolumn{1}{c}{ Total } & 354 & \\
\hline
\end{tabular}

Hasil penelitian menunjukkan kerusakan yang terjadi di jalur hijau dan halaman parkir Unila sebagian besar kurang membahayakan kesehatan pohon karena kerusakan terjadi jauh dari bagian akar. Semakin dekat lokasi kerusakan dengan lokasi akar maka semakin berbahaya terhadap kesehatan pohon. Berdasarkan metode Forest Health Monitoring (FHM), tanda dan gejala kerusakan diberi prioritas dan dicatat berdasarkan lokasi menurut urutan : akar, akar dan batang bagian bawah, batang bagian bawah, batang bagian bawah dan batang bagian atas, batang bagian atas, batang tajuk, cabang, kuncup dan tunas serta daun (Mangold, 1997).

\section{KESIMPULAN DAN SARAN}

Sebagian besar kondisi pohon di jalur hijau dan halaman parkir di lingkungan Universitas Lampung berada pada kondisi sehat $(92,29 \%)$ dan hanya sebagian kecil $(7,81 \%)$ yang berada pada kondisi rusak ringan, rusak sedang, dan rusak berat. Secara umum terdapat 9 tipe kerusakan pohon yang paling sering ditemukan pada pohon-pohon penyusun vegetasi jalur hijau dan halaman parkir Unila. Kerusakan-kerusakan yang dialami adalah perubahan warna daun (10.48\%), luka terbuka (10.38\%), tubuh buah (4.11\%), kanker (3.80\%), epifit (2.26\%), 
kerusakan tunas daun (1.23\%), patah cabang/batang (1.54\%), branchis 0.92, dan resinosis $(0.51 \%)$.

Warga civitas akademika Universitas Lampung hendaknya tidak melakukan publikasi dengan memanfaatkan pohon sebagai media sehingga dapat menurunkan kesehatan pohon. Pohon-pohon yang berstatus rusak sedang hendaknya diberikan perawatan dan pemeliharaan, sehingga status kesehatan rusak ringan dan rusak sedang dapat meningkat menjadi sehat. Sedangkan pohon yang berada pada kondisi rusak berat atau mati hendaknya dilakukan penebangan agar tidak membahayakan warga civitas akademika Unila.

\section{DAFTAR PUSTAKA}

Djayapertjunda. 2003. Pengembangan Hutan Milik Di Jawa. Buku. Mada University Press. Jogyakarta. $129 \mathrm{p}$.

Duryat, Gitosaputro, S., dan Melya, R. 2014. Analisis status dan pemetaan kondisi kesehatan pohon penghijauan di Kota Bandar Lampung. Laporan Penelitian. Universitas Lampung. Lampung. 20 p.

Mangold, R. 1997. Forest Health Monitoring: Field Methods Guide. Book. USDA Forest. 135 p. Mawazin dan Suhaendi, H. 2007. Pengaruh jarak tanam terhadap pertumbuhan diameter Shorea parvifolia Dyer. Jurnal Penelitian Hutan dan Konservasi Alam. 5(4): 381-388.

Siregar, B.N.T.MP. 2014. Evalusi kesehatan pohon peneduh di Kota Bandar Lampung berbasis sonic tomography. Jurnal Teknologi Hasil Hutan. 27(2): 20-29.

Sobirin, M. 2010. Pendugaan karbon tersimpan di atas tanah di Arboretum Universitas Lampung. Skripsi. Universitas Lampung. Bandar Lampung. 49 p.

Sumardi dan Widyastuti, M.S. 2004 Dasar-Dasar Perlindungan Hutan. Buku. Gadjah Mada University Press. Jogyakarta. 139 p.

Stalin, M., Farah, D., dan Harnani, H. 2011. Analisis kerusakan pohon di Jalan Ahmad Yani Kota Pontianak. Jurnal Hutan Lestari. 1(2): 100-107.

Syam, T., Kushendarto., Bintoro, A., dan Indriyanto. 2007. Keanekaragaman Pohon Di Kampus Hijau Unila. Buku. Universitas Lampung. Bandar Lampung. 122 p.

Triwibowo, H., Jumani, dan Emawati, H. 2014. Identifikasi hama dan penyakit Shorea leprosula Miq di Taman Nasional Kutai Resort Sangkima Kabupaten Kutai Timur Provinsi Kalimantan Timur. Jurnal AGRIFOR. 13(2): 175-184.

Widyastuti, Sumardi, dan Harjono. 2005. Patologi Hutan. Buku. Gadjah Mada University Press. Yogyakarta. $139 \mathrm{p}$.

Yudiarti, T. 2012. Ilmu Penyakit Tumbuhan. Buku. Graha Ilmu. Yogyakarta. 117 p. 